\title{
PENINGKATAN PRESTASI BELAJAR MATEMATIKA SISWA KELAS X MIPA 7 SMA NEGERI 1 SINGARAJA MELALUI PENERAPAN TEKNIK MIND MAP
}

\author{
${ }^{1}$ I P. A. Y. Anggara Kusuma, ${ }^{2}$ I P. Wisna Ariawan \\ 1,2Jurusan Pendidikan Matematika \\ Universitas Pendidikan Ganesha \\ Singaraja, Indonesia \\ e-mail: anggara.agusyoga@gmail.com,wisnab36@gmail.com
}

\begin{abstract}
Abstrak
Penelitian ini bertujuan untuk menganalisis peningkatan prestasi belajar matematika melalui teknik mind map pada siswa kelas X MIPA 7 SMA Negeri 1 Singaraja. Penelitian ini termasuk jenis penelitian tindakan kelas yang terdiri dari dua siklus dan setiap siklus terdiri dari 4 tahap yaitu perencanaan, pelaksanaan, pengamatan, dan refleksi. Subjek dalam penelitian ini adalah peneliti sebagai pelaku tindakan, guru sebagai pengamat dan siswa kelas X MIPA 7 yang berjumlah 32 orang sebagai penerima tindakan. Metode pengumpulan data yang digunakan meliputi metode observasi, dokumentasi, wawancara dan tes. Data yang dikumpulkan dalam penelitian ini adalah data prestasi belajar matematika siswa untuk materi pertidaksamaan linier kuadrat dua variabel. Teknik analisis data dilakukan dengan mencari rata-rata skor dari hasil tes prestasi belajar matematika siswa. Selain itu dideskripsikan pula ketuntasan belajar dari setiap siklusnya. Ketuntasan klasikal dihitung berdasarkan banyaknya siswa yang mencapai nilai tuntas berbanding dengan jumlah seluruh siswa dalam kelas. Data hasil penelitian menunjukkan bahwa prestasi belajar matematika siswa mengalami peningkatan. Ditinjau dari rata-rata hasil tes prestasi belajar pada siklus I meningkat dari reflesksi awal 67,44 menjadi 74,84. Hasil tes prestasi belajar pada siklus I masih di bawah KKM, sehingga tindakan dilanjutkan ke siklus II. Pada siklus II rata-rata hasil tes prestasi belajar meningkat menjadi 79,16. Ditinjau dari ketuntasan belajar, peningkatan terjadi dari refleksi awal banyak siswa yang tuntas 16 orang $(50,00 \%)$ meningkat pada siklus I menjadi 21 orang $(65,63 \%)$ dan meningkat lagi pada siklus II menjadi 26 orang $(81,25 \%)$. Berdasarkan hasil tersebut dapat disimpulkan bahwa teknik mind map dapat meningkatkan prestasi belajar matematika siswa.
\end{abstract}

Keywords: mind map, prestasi belajar, pertidaksamaan linier kuadrat dua variabel

\begin{abstract}
This study aims to find out to improvement mathematics learning achievement through mind map techniques in class X MIPA 7 SMA Negeri 1 Singaraja. This research is a type of classroom action research which consists of two cycles and each cycle consists of 4 stages, namely planning, implementing, observing, and reflecting. Subjects in this study were researchers as actors, teachers as observers and students of class X MIPA 7 totaling 32 people as recipients of action. Data collection methods used include methods of observation, documentation, interviews and tests. The data collected in this study is the data of students' mathematics learning achievement for linear quadratic inequality two variables. Data analysis techniques were carried out by looking for an average score from the results of students' mathematics learning achievement tests. Besides that, also described the completeness of learning from each cycle. Classical completeness is calculated based on the number of students who achieve complete scores compared to the number of all students in the class. Research data shows that students' mathematics learning achievement has increased. Judging from the average learning achievement test results in the first cycle, it increased from
\end{abstract}


an initial reflection of 67.44 to 74.84 . The results of the learning achievement test in the first cycle are still below the KKM, so the action continues to cycle II. In the second cycle the average learning achievement test results increased to 79.16. Judging from the completeness of learning, an increase occurred from the initial reflection of many students who completed 16 people (50.00\%) increased in the first cycle to 21 people (65.63\%) and increased again in the second cycle to 26 people (81.25\%). Based on these results it can be concluded that mind map techniques can improve students' mathematics learning achievement.

Keywords: mind map, learning achievement, linear inequality squared two variables

\section{Pendahuluan}

Kegiatan utama dalam proses pendidikan di sekolah adalah kegiatan pembelajaran. Proses pembelajaran yang dilakukan merupakan penentu keberhasilan dalam mencapai tujuan pendidikan nasional. Siswa yang terlibat dalam proses pembelajaran diharapkan mengalami perubahan baik dalam bidang pengetahuan, pemahaman, keterampilan, nilai dan sikap. Dalam proses pembelajaran di sekolah guru akan menghadapi siswa yang mempunyai karakteristik berbeda-beda sehingga guru tidak akan lepas dengan masalah hasil belajar.

Keberhasilan dalam proses belajar mengajar di sekolah tergantung kepada beberapa aspek yaitu sarana prasarana, guru, siswa dan metode pembelajaran. Aspek yang dominan dalam proses belajar mengajar adalah guru dan siswa. Kegiatan yang dilakukan guru dan siswa dalam hubungannya dengan pendidikan disebut kegiatan belajar mengajar. Guru sebagai motivator dan fasilitator sedangkan siswa sebagai penerima informasi yang diharapkan dapat lebih aktif dalam kegiatan belajar mengajar.

Matematika merupakan salah satu alat bantu IImu Pengetahuan dan Teknologi yang memegang peranan penting dalam berbagai bidang (Dipayana et al., 2019). Kemampuan siswa dalam bidang ilmu pengetahuan dan matematika selain berpengaruh dalam mempelajari matematika itu sendiri juga berpengaruh terhadap bidang ilmu lain.

Mengingat bahwa dalam proses belajar-mengajar, seorang siswa sering mengalami kesulitan atau hambatan dalam memahami atau menguasai suatu materi pelajaran dari suatu bidang studi tertentu, yang disebabkan oleh beberapa faktor. Baik itu yang bersifat eksternal maupun internal, dan di samping itu prestasi belajar yang dicapai juga sangat dipengaruhi oleh penguasaan bidang studi itu sendiri. Hal ini yang mengundang perhatian banyak orang terutama para ahli kependidikan. Hal ini disebabkan oleh adanya kesadaran pada diri mereka bahwa di era seperti saat ini pendidikan merupakan salah satu pilar pembangunan bangsa. Secara khusus pendidikan matematika selalu menjadi sorotan karena masih relatif rendahnya hasil belajar siswa pada bidang studi matematika.

Berdasarkan hasil wawancara dan observasi proses pembelajaran yang dilaksanakan di Kelas X MIPA 7 SMA Negeri 1 Singaraja ditemukan permasalahan. Adapun permasalahan tersebut meliputi:

Pertama, dari pembelajaran di kelas terlihat bahwa guru lebih dominan dalam penyampaian konsep-konsep pada materi pokok dan langkah-langkah pengerjaan pada tiaptiap soal yang diberikan. Kebanyakan siswa menjadi bingung apabila dihadapkan kepada soalsoal yang dibuat sedikit berbeda, padahal apabila konsep dapat dipegang oleh siswa, siswa sebenarnya mampu untuk menyelesaikan soal-soal dengan baik. Keadaan seperti ini membuat siswa tidak dapat mengembangkan konsep pembelajaran terhadap masalahmasalah matematika yang berkaitan dengan kehidupan nyata yang ada di sekitar siswa.

Kedua, Guru jarang menggunakan media pembelajaran atau garis besar pembelajaran. Pembelajaran dilakukan secara umum menggunakan latihan soal yang disesuaikan dengan konsep-konsep yang telah dipelajari sebelumnya. Hal ini akan membuat siswa akan membuat model matematika yang hanya bersumber kepada konsep-konsep yang telah dipelajari. Keadaan seperti ini mengakibatkan siswa menjadi kurang optimal dalam memecahkan masalah konstekstual.

Permasalahan di atas mengarah pada prestasi belajar siswa yang masih rendah. Menurut Hamalik (2004:8) prestasi adalah suatu keberhasilan yang dicapai siswa setelah 
melakukan suatu proses kegiatan belajar mengajar dalam kurun waktu tertentu sesuai dengan tujuan yang telah ditentukan. Prestasi belajar ini sering dicerminkan sebagai nilai (hasil belajar) yang menentukan berhasil atau tidaknya peserta didik dalam pembelajaran.

Belajar dapat dipengaruhi oleh beberapa faktor yang terdiri dari faktor intern dan faktor ekstern. Dimyati dan Mudjiono (2006: 239) mengemukakan faktor intern yang dialami dan dihayati oleh peserta didik yang berpengaruh pada proses belajar yaitu (1) Sikap terhadap belajar, (2) Motivasi belajar, (3) Konsentrasi belajar, (4) Mengolah bahan ajar, (5) Menyimpan perolehan hasil belajar, (6) Menggali hasil belajar yang tersimpan, (7) Kemampuan berprestasi atau unjuk hasil belajar, (8) Rasa percaya diri siswa, (9) Intelegensi dan keberhasilan belajar, (10) Kebiasaan belajar, dan (11) Cita-cita siswa. Faktor ekstern yang berpengaruh pada aktivitas belajar mencakup (1) Guru sebagai pembina siswa belajar, (2) Prasarana dan sarana pembelajaran, (3) kebijakan penilaian, (4) lingkungan sosial siswa di sekolah, dan (5) kurikulum sekolah.

Rendahnya prestasi belajar matematika siswa juga ditunjukkan dengan hasil tes awal kemampuan berupa penilaian harian siswa yang ditunjukkan pada tabel yaitu dari 32 siswa, hanya 16 siswa yang mampu mencapai kriteria ketuntasan minimal sebesar 75 . Hal ini masih dinilai kurang dalam ketuntasan klasikal sehingga penulis merasa perlu untuk melakukan terobosan pembelajaran yang bersifat lebih variatif.

Salah satu alternatif yang dapat digunakan yaitu dengan teknik mind map. Teknik ini menggunakan menggambar konsep yang telah diketahui oleh siswa dengan menggunakan warna-warna yang disukai oleh siswa, sehingga siswa dapat membaca dengan lebih antusias yang pada akhirnya siswa dapat belajar dengan lebih baik. Di samping itu, teknik ini dibuat dengan menggunakan bentuk yang mudah digambar seperti garis dan lingkaran, atau bentuk yang disukai oleh siswa seperti pohon, bunga, dan lain sebagainya.

Menurut Buzan (2008: 4), Mind map merupakan alat yang membantu otak berpikir secara teratur dan sederhana sehingga mudah untuk memasukkan informasi ke otak dan mengambil informasi dari otak. Struktur Mind map yaitu memancar keluar dari gambar pusat yang menggunakan garis, lambang, kata-kata, gambar, yang akrab bagi otak peserta didik. Berdasarkan pemikiran di atas, maka penulis bermaksud untuk melakukan suatu penelitian dalam bentuk penelitian tindakan kelas dengan judul "Peningkatan Prestasi Belajar Matematika Siswa Kelas X MIPA 7 SMA Negeri 1 Singaraja Melalui Penerapan Teknik Mind Map" dengan harapan nantinya penelitian ini dapat berguna dalam dunia pendidikan khususnya dan ilmu pengetahuan pada umumnya. Rumusan masalah dalam penelitian ini adalah bagaimana peningkatan prestasi belajar Bagaimana teknik mind map dapat meningkatkan prestasi belajar matematika siswa kelas X MIPA 7 SMA Negeri 1 Singaraja?? Adapun tujuan dari penelitian ini adalah untuk mengetahui peningkatan prestasi belajar matematika melalui teknik mind map pada siswa kelas X MIPA 7 SMA Negeri 1 Singaraja.

\section{Metode}

Penelitian ini termasuk penelitian tindakan kelas yang bertujuan untuk memperbaiki proses pembelajaran di kelas X MIPA 7 SMA Negeri 1 Singaraja sehingga dapat meningkatkan prestasi belajar matematika siswa melalui penerapan model pembelajaran discovery learning. Tahapan yang dilakukan dalam penelitian tindakan kelas ini yaitu (1) perencanaan, (2) pelaksanaan, (3) pengamatan, dan (4) refleksi. Penelitian ini bersifat kolaboratif karena tidak hanya melibatkan siswa saja tetapi peneliti juga bekerjasama dengan guru matematika yang mengajar di kelas X MIPA 7 SMA Negeri 1 Singaraja.

Subjek dalam penelitian ini adalah siswa kelas X MIPA 7 SMA Negeri 1 Singaraja semester ganjil tahun ajaran 2018/2019 yang berjumlah 32 orang. Pemilihan subjek tersebut dikarenakan peneliti mendapatkan permasalahan mengenai prestasi belajar matematika siswa yang masih rendah. Sedangkan objek dalam penelitian tindakan kelas yang dilakukan ini adalah prestasi belajar matematika siswa kelas X MIPA 7 SMA Negeri 1 Singaraja terhadap teknik mind map pada semester ganjil tahun ajaran 2018/2019.

Penelitian ini dimulai dengan melalukan refleksi awal yang bertujuan untuk: (1) mengidentifikasi permasalahan dan kendala baik yang dialami oleh siswa maupun guru, (2) 
mengetahui kelemahan dalam proses pembelajaran di dalam kelas, dan (3) mencari solusi dalam pemecahan masalah tersebut. Dari hasil identifikasi tersebut diperoleh gambaran umum mengenai proses pembelajaran yang berlangsung di kelas X MIPA 7, kemudian disusun rencana serta langkah-langkah untuk menerapkan Teknik Mind Map dalam pembelajaran matematika sehingga mampu meningkatkan prestasi belajar matematika siswa kelas X MIPA 7 SMA Negeri 1 Singaraja tahun ajaran 2018/2019.

Dalam siklus I dilakukan beberapa langkah antara lain: perencanaan tindakan, pelaksanaan tindakan, observasi dan evaluasi, serta melakukan refleksi pada akhir siklus. Pertemuan pada siklus I dilaksanakan dalam 3 kali pertemuan dengan satu pertemuan terakhir untuk pelaksanaan tes siklus I. Berdasarkan hasil refleksi awal, dapat dirumuskan beberapa hal yang perlu direncanakan dalam penelitian ini, diantaranya : (1) Menentukan sejauh mana materi yang akan dibahas pada siklus I. (2) Menyamakan persepsi dengan guru matematika kelas X MIPA 7 SMA Negeri 1 Singaraja mengenai pembelajaran matematika dengan teknik mind map. (3) Merumuskan indikator pembelajaran untuk masing-masing pertemuan berdasarkan Kompetensi Inti (KI), dan Kompetensi Dasar (KD) yang tercantum pada kurikulum 2013 (K13). (4) Merumuskan tujuan pembelajaran dari indikator masing-masing kompetensi dasar (KD). (5) Menyusun langkah-langkah pembelajaran sesuai dengan langkah-langkah model pembelajaran. (6) Merancang dan menyiapkan lembar kerja siswa, latihan soal, tes kuis dan tugas (7) Mengidentifikasi kemampuan masing-masing siswa sebagai pedoman untuk membagi kelompok agar terbentuk kelompok yang heterogen. (8) Membagi siswa menjadi beberapa kelompok. Masing-masing kelompok beranggotakan 4 orang yang heterogen dalam kemampuan siswa dalam bidang akademik. (9) Menyusun instrumen untuk mengukur prestasi belajar fungsi siswa dengan tes siklus I.

Pelaksanaan tindakan siklus I dilakukan dengan menerapkan teknik mind map yang dilakukan secara bersama oleh guru dan siswa. Proses pembelajaran dilakukan sesuai dengan jadwal pelajaran matematika siswa kelas X MIPA 7 SMA Negeri 1 Singaraja. Adapun tindakan yang dilakukan dalam pembelajaran matematika menggunakan teknik mind map melalui beberapa tahapan, yaitu tahap memberikan orientasi permasalahan kepada peserta didik, tahap mengorganisasikan peserta didik untuk penyelidikan, tahap pertanyaan/identifikasi masalah, tahap Pelaksanaan penyelidikan individual dan kelompok, tahap Mengembangkan dan menyajikan hasil karya berupa mind map, dan tahap Menganalisis dan mengevaluasi proses penyelidikan .

Kegiatan observasi dilaksanakan secara kontinu selama pembelajaran berlangsung. Observasi dilakukan oleh peneliti dan guru terhadap proses pembelajaran yang berlangsung, untuk mengetahui kegiatan serta tingkah laku siswa selama proses pembelajaran. Hal ini bisa menjadi bahan pertimbangan peneliti dalam perencanaan tindakan pada siklus selanjutnya. Adapun hal-hal yang diobservasi dan dievaluasi diantaranya: (1) Observasi pembelajaran matematika dengan teknik mind map dan kinerja siswa dalam menyelesaikan bentuk mind map yang diberikan selama siklus I; (2) Evaluasi hasil pembelajaran di akhir siklus I berdasarkan tes prestasi belajar; (3) Kolaborasi antara guru dan peneliti dalam mengevaluasi pembelajaran dengan menggunakan teknik mind map pada siklus I; (4) Mencatat hambatanhambatan dan kekurangan-kekurangan yang ditemukan selama proses pembelajaran pada pelaksanaan tindakan siklus I.

Pada akhir siklus I, peneliti melakukan refleksi terhadap pelaksanaan pembelajaran selama proses pembelajaran berlangsung. Refleksi dilaksanakan berdasarkan hasil observasi dan evaluasi yang telah dilakukan sebelumnya. Refleksi dilakukan peneliti bersama guru dengan mendiskusikan hambatan-hambatan dan kekurangan-kekurangan yang dihadapi pada tindakan siklus I untuk dijadikan pertimbangan dalam melaksanakan perencanaan yang lebih baik pada siklus selanjutnya.

Pada siklus II perencanaan tindakan yang dilakukan merupakan penyempurnaan dari tindakan yang dilakukan pada siklus I. Hasil refleksi dari siklus I digunakan sebagai acuan dalam pelaksanaan siklus II. Tahapan pada siklus kedua identik dengan siklus pertama yaitu diawali dengan perencanaan tindakan, dilanjutkan dengan pelaksanaan tindakan, observasi, 
dan refleksi tindakan. Pertemuan pada siklus II dilaksanakan dalam tiga kali pertemuan dengan satu pertemuan terakhir untuk pelaksanaan tes prestasi belajar matematikai siswa.

Data yang diperlukan dalam penelitian ini meliputi data tentang prestasi belajar matematika. Secara rinci jenis data yang akan dikumpulkan, teknik pengumpulan data, instrumen, dan waktu pengumpulan data dalam penelitian ini disajikan dalam tabel 1 berikut.

Tabel 1. Jenis Instrumen dan Metode Pengumpulan Data

\begin{tabular}{lllll}
\hline No & Jenis Data & $\begin{array}{l}\text { Teknik } \\
\text { Pengumpulan Data }\end{array}$ & $\begin{array}{l}\text { Instrumen } \\
\text { Penelitian }\end{array}$ & Waktu \\
\hline 1. & $\begin{array}{l}\text { Prestasi belajar } \\
\text { matematika }\end{array}$ & Tes & Uraian & $\begin{array}{l}\text { Pada akhir dari masing- } \\
\text { masing siklus }\end{array}$ \\
\hline
\end{tabular}

Data yang dikumpulkan dalam penelitian ini adalah data pencapaian kompetensi matematika siswa untuk topik pertidaksamaan linier kuadrat dua variabel. Adapun teknik pengumpulan data untuk pencapaian kompetensi matematika siswa adalah melalui tes bentuk uraian yang telah dirancang sesuai dengan topik atau kompetensi yang sedang diajarkan. Pemberian tes dilaksanakan pada setiap akhir siklus. Data yang dikumpulkan melalui tes selanjutnya dianalisis untuk memperoleh gambaran mengenai tingkat keberhasilan pelaksanaan tindakan yang diberikan, dalam hal ini berupa pembelajaran dengan model discovery learning. Data capaian prestasi belajar matematika siswa dianalisis secara deskriptif, dengan terlebih dahulu mencari rata-rata skor dari hasil tes prestasi belajar matematika siswa.

Formula yang digunakan untuk mencari rata-rata skor capaian kompetensi matematika siswa:

$$
\bar{X}=\frac{\sum X}{N}
$$

dengan $\bar{X}$ adalah rata-rata skor prestasi belajar matematika siswa, $\sum X$ adalah jumlah skor seluruh siswa yang mengikuti tes prestasi belajar matematika, dan $N$ adalah banyaknya siswa yang mengikuti tes prestasi belajar matematika.

Rata-rata skor prestasi belajar matematika siswa setiap siklus dianalisis untuk kemudian dibandingkan pada setiap siklusnya. Tujuannya adalah untuk melihat kenaikan atau penurunan prestasi belajar matematika siswa. Selain melihat rata-rata kelas, juga akan dideskripsikan ketuntasan belajar dari setiap siklusnya. Ketuntasan klasikal dihitung berdasarkan banyaknya siswa yang mencapai nilai tuntas secara individual $(\geq 75)$ berbanding jumlah seluruh peserta didik dalam kelas dari siklus I.

Penelitian ini dikatakan berhasil jika memenuhi kriteria: (1) rata-rata nilai prestasi belajar siswa minimal mencapai kategori tuntas $(\geq 75),(2)$ ketuntasan belajar kelas yang dijadikan subjek penelitian minimal $80 \%$.

\section{Hasil dan Pembahasan}

Sebagaimana yang telah diuraikan sebelumnya bahwa penelitian ini dilaksanakan pada semester ganjil tahun ajaran 2018/2019 di SMA Negeri 1 Singaraja dari tanggal 17 September sampai dengan 5 Oktober 2018, dengan subjek penelitian adalah siswa kelas X MIPA 7 yang berjumlah 32 orang. Penelitian tindakan kelas ini terlaksana dalam dua siklus. Adapun rincian pembelajaran pada setiap siklus dapat dilihat pada tabel 2 berikut. 
Tabel 2. Rincian Materi Pembelajaran setiap Siklus

\begin{tabular}{|c|c|c|c|}
\hline Tahapan & \multicolumn{2}{|c|}{ Materi Pelajaran } & $\begin{array}{l}\text { Banyak } \\
\text { Pertemuan }\end{array}$ \\
\hline \multirow{3}{*}{ Siklus I } & Pertidaksamaan & $\begin{array}{l}\text { Pertidaksamaan Kuadrat Dua } \\
\text { Variabel }\end{array}$ & 1 kali \\
\hline & $\begin{array}{l}\text { Linier Kuadrat Dua } \\
\text { Variabel }\end{array}$ & $\begin{array}{c}\text { Pertidaksamaan Linier Kuadrat } \\
\text { Dua Variabel }\end{array}$ & 1 kali \\
\hline & & Evaluasi & 1 kali \\
\hline \multirow{2}{*}{ Siklus II } & $\begin{array}{l}\text { Pertidaksamaan } \\
\text { Kuadrat-Kuadrat }\end{array}$ & $\begin{array}{c}\text { Pertidaksamaan Kuadrat Kuadrat } \\
\text { Dua Variabel }\end{array}$ & 2 kali \\
\hline & Dua Variabel & Evaluasi & 1 kali \\
\hline
\end{tabular}

Sebelum melaksanakan penelitian, peneliti telah melakukan refleksi awal terhadap siswa kelas X MIPA 7 di SMA Negeri 1 Singaraja. Refleksi awal dilakukan dengan mengadakan wawancara dengan guru yang bersangkutan, dan observasi kelas. Hasil wawancara dengan guru matematika yang bersangkutan dikatakan pula bahwa materi pertidaksamaan linier kuadrat juga merupakan materi yang sulit dipahami oleh siswa karena siswa diharuskan untuk menggambarkan grafik dan menentukan daerah penyelesaian dari gambar tersebut. Di samping itu, pada penilaian harian sebelumnya menunjukan bahwa siswa masih lemah terhadap konsep meteri yang diajarkan. Oleh karena itu, diperlukan tindakan untuk mengatasi permasalahan tersebut. Penelitian tindakan kelas ini dilakukan dalam 2 siklus.

Berdasarkan hasil analisis data pada siklus I menunjukkan bahwa nilai terendah adalah 60 dan nilai tertinggi adalah 86. Hasil tes tersebut juga menunjukkan bahwa dari 32 orang siswa, 21 orang yang berada pada kategori tuntas. Adapun sebaran hasil tes pada siklus I disajikan Gambar 1 berikut.

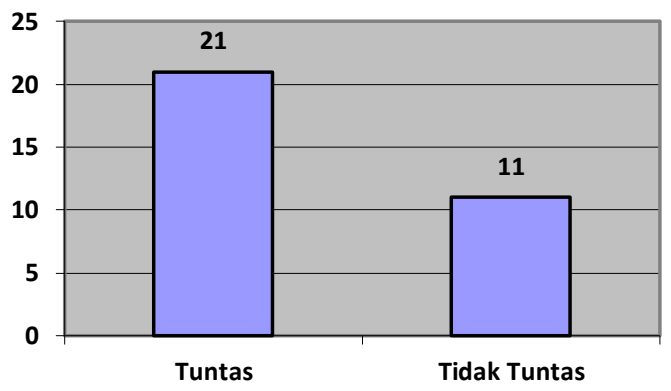

\section{Gambar 1. Sebaran Prestasi Belajar Matematika Siswa pada Siklus I}

Secara umum, proses pembelajaran pada siklus I dengan penerapan teknik mind map belum dapat berjalan secara optimal sehingga perlu dilakukan beberapa perbaikan. Hal ini dapat dilihat dari rata-rata nilai tes prestasi belajar pada siklus I yang masih berada dalam kategori belum tuntas. Dari hasil observasi secara umum, masih ditemukan beberapa permasalahan dalam proses pembelajaran yang perlu dijadikan pertimbangan untuk proses perbaikan dalam pelaksanaan siklus berikutnya. Adapun permasalahan yang menyebabkan belum tuntas dan belum optimalnya pembelajaran pada siklus I diantaranya adalah sebagai berikut. (1) Siswa masih menyesuaikan diri untuk mengikuti pembelajaran dengan teknik mind map. Saat mengerjakan Lembar Kerja Peserta Didik (LKPD) masih banyak siswa yang kebingungan maupun siswa yang ragu-ragu untuk menuliskan jawabannya; (2) Dalam diskusi kelompok pertanyaan lebih sering diajukan oleh siswa yang pintar kepada guru sedangkan anggota kelompok yang lain hanya mendengarkan; (3) Penyampaian hasil diskusi masih didominasi oleh siswa yang pintar; (4) Penggunaan waktu yang kurang optimal oleh siswa. Siswa kurang bisa memanfaatkan waktu untuk berdiskusi dalam menyelesaikan 
permasalahan dalam LKPD. Hal ini ditunjukkan ketika guru mengamati tiap-tiap kelompok, masih ada siswa yang mendiskusikan hal di luar topik pembelajaran; (5) Siswa belum terbiasa untuk membuat kesimpulan secara individu saat pembelajaran, sehingga masih banyak siswa hanya menulis kesimpulan yang dibuat oleh temannya. Bahkan, ada juga siswa yang sama sekali tidak membuat kesimpulan pada bukunya; (6) Pengumpulan tugas belum berlangsung optimal karena masih ada beberapa siswa yang terlambat mengumpulkan bahkan sama sekali tidak mengumpulkan sampai batas waktu terakhir pengumpulan tugas. Selain itu banyak siswa yang tidak melakukan refleksi diri dari latihan dan kesimpulan hasil diskusi, tugas, dan kuis yang diberikan.

Hasil pada siklus I belum memenuhi indikator keberhasilan, sehingga tindakan dilanjutkan pada siklus II. Berdasarkan hasil analisis data pada siklus II menunjukkan bahwa nilai terendah adalah 68 dan nilai tertinggi adalah 88. Hasil tes tersebut juga menunjukkan bahwa dari 32 orang siswa, 26 orang siswa sudah tuntas. Pada siklus II diperoleh rata-rata kelas yaitu 79,16. Adapun sebaran prestasi belajar siswa pada siklus II dapat disajikan pada Gambar 2 berikut.

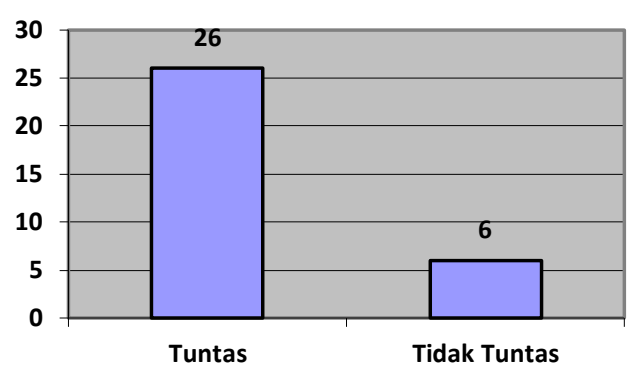

Gambar 2. Sebaran Prestasi Belajar Matematika Siswa pada Siklus II

Berdasarkan hasil refleksi siklus II terlihat bahwa pembelajaran pada siklus II, baik dari segi hasil maupun proses menunjukkan peningkatan dari siklus sebelumnya. Adapun temuantemuan selama pelaksanaan tindakan siklus II diantaranya: (1) proses pembelajaran secara umum sudah berlangsung sesuai dengan RPP yang telah disusun; (2) intensitas bimbingan guru lebih sedikit dari pelaksanaan siklus sebelumnya karena siswa telah terbiasa menyelesaikan permasalahan yang diberikan dengan melakukan diskusi kelompok; (3) banyak siswa yang sudah berani mengajukan pendapat maupun menyampaikan hasil diskusi tanpa ditunjuk; (4) Pengumpulan tugas telah dilaksanakan dengan baik, sekaligus perbaikan yang dilakukan oleh siswa telah mengalami peningkatan. Hal ini dapat dilihat dari tingkat kesalahan siswa pada hal yang sama sudah menurun. Selain itu, siswa juga antusias dalam membuat mind map; (5) Beberapa siswa yang masih memiliki nilai pemahaman konsep yang rendah atau masih berada dalam kategori belum tuntas, perlu mendapatkan bimbingan yang lebih serius lagi pada pembelajaran berikutnya.

Ringkasan hasil tes prestasi belajar siswa pada refleksi awal, siklus I dan siklus II dapat dilihat pada tabel 3 berikut.

Tabel 3. Ringkasan Hasil Tes Prestasi Belajar Siswa

\begin{tabular}{cccccccc}
\hline \multirow{2}{*}{ No } & \multirow{2}{*}{ Kategori } & \multicolumn{2}{c}{ Tes Awal } & \multicolumn{2}{c}{ Siklus I } & \multicolumn{2}{c}{ Siklus II } \\
\cline { 2 - 8 } & F & P & F & P & F & P \\
\hline 1 & Belum Tuntas & 16 & $50,00 \%$ & 11 & 25,16 & 6 & 18,75 \\
2 & Tuntas & 16 & $50,00 \%$ & 21 & 74,84 & 26 & 81,25 \\
\hline & Rata-rata Nilai & \multicolumn{2}{c}{67,44} & \multicolumn{2}{c}{74,84} & \multicolumn{2}{c}{79,16} \\
\hline
\end{tabular}

Keterangan:

$\mathrm{F}=$ Frekuensi

$\mathrm{P}=$ Persentase 
Berdasarkan Tabel 3 di atas, secara umum terlihat bahwa prestasi belajar matematika siswa kelas X MIPA 7 SMA Negeri 1 Singaraja mengalami peningkatan dari refleksi awal sampai siklus II. Peningkatan nilai rata-rata siswa dari refleksi awal ke siklus I adalah 7,40 dan peningkatan nilai rata-rata siswa dari refleksi awal ke siklus II adalah 11,72. Peningkatan nilai rata-rata prestasi belajar siswa pada tahap refleksi awal, siklus I, dan siklus II dapat disajikan dalam Gambar 3 berikut.

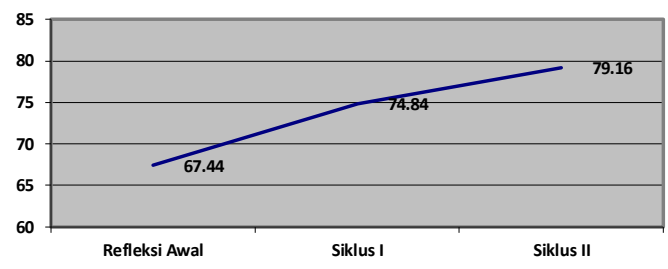

Gambar 3. Sebaran Nilai Rata-rata Hasil Tes Setiap Siklus

\section{Pembahasan}

Berdasarkan refleksi awal ditunjukkan bahwa prestasi belajar matematika masih rendah. Hal ini terlihat dari penilaian harian sebelumnya yaitu dari 32 orang, hanya 16 orang yang mencapai kriteria ketuntasan minimal, sehingga diperlukan suatu tindakan untuk dapat meningkatkan prestasi belajar matematika siswa dengan menerapkan teknik mind map.

Dari hasil tindakan dengan menerapkan teknik mind map yang dilaksanakan selama dua siklus, peningkatkan optimal prestasi belajar siswa terjadi pada siklus II. Hasil penelitian menunjukkan bahwa rata-rata prestasi belajar siswa pada siklus I sebesar 74,84 , rata-rata prestasi belajar siswa pada siklus II sebesar 79,16. Hal ini menunjukkan bahwa indikator keberhasilan pada poin pertama dalam penelitian ini telah tercapai.

Peningkatan yang terjadi pada siswa, tidak lepas dari penerapan teknik mind map dengan tahapan yakni pertama tahap berhadapan dengan masalah, pada tahap ini siswa dilatih untuk berusaha mengetahui tujuan dari permasalahan yang diberikan. Kedua tahap pengenalan konsep, di mana guru memberikan konsep-konsep penting yang kemudian siswa menerapkannya pada LKPD yang diberikan. Kegiatan ini dilakukan melalui diskusi baik dengan teman dalam kelompoknya maupun dengan guru. Namun, bimbingan yang diberikan oleh guru hanya mengarahkan siswa, sehingga penyelesaiaan dapat dilakukan oleh siswa secara mandiri. Ketiga tahap komunikasi, merupakan tahap bagi siswa untuk mengkomunikasikan yang diperoleh dari hasil diskusi bersama kelompoknya. Pada tahap ini siswa yang lain mencermati hasil yang disampaikan serta diberikan kesempatan untuk bertanya, memberikan tanggapan maupun menyampaikan pendapatnya. Keempat tahap penarikan kesimpulan, merupakan tahap bagi siswa untuk merumuskan kesimpulan yang memuat jawaban yang tepat berdasarkan hasil diksusi. Kelima tahap pembuatan mind map, siswa diberikan kesempatan untuk membuat mind map. Pembuatan mind map didasarkan dengan apa saja yang konsep yang didapat oleh siswa secara bebas. Siswa bebas menuliskan konsep-konsep yang telah didapat.

Dalam proses pembelajaran yang dilakukan pada siklus I, dan II kegiatan pembelajaran juga dilakukan dengan teknik mind map, namun dengan mempertahankan upaya perbaikan pada siklus I dan menerapkan upaya perbaikan yang dilaksanakan pada siklus II. Adapun upaya perbaikan yang menyebabkan terjadinya peningkatan prestasi belajar adalah sebagai berikut.

Pertama, pada proses pembelajaran guru akan mengoptimalkan pertanyaanpertanyaan arahan dalam menggali kembali konsep yang sudah dipelajari sebelumnya dengan memberikan catatan-catatan penting yang ditunjukkan pada bentuk mind map. Kegiatan ini lebih banyak dilakukan saat guru memberikan apersepsi, sehingga mengurangi kesulitan siswa menyelesaikan permasalahan dalam LKPD dan siswa dapat melakukan diskusi bersama kelompoknya sehingga dapat mengkonstruksi konsep baru secara mandiri. 
Kedua, dengan memberikan beberapa latihan soal setelah dilakukannya diskusi kelompok, dan memberikan konsep-konsep yang perlu diperhatikan untuk memecahkan persoalan yang diberikan. Dengan menyelesaikan permasalahan-permasalahan secara intensif kepada siswa tentunya akan meningkatkan pemahaman konsep siswa terhadap materi yang sedang dipelajari khususnya dalam mengaplikasikan konsep dalam berbagai situasi. Ketiga, pemberian motivasi kepada siswa juga dapat dilakukan untuk membuat siswa lebih aktif dalam bentuk menunjuk siswa secara acak untuk memberikan pendapatnya ataupun menanggapi pertanyaan dari kelompok lain. Hal itu akan membuat siswa akan lebih siap memberikan pendapatnya dan memberikan dorongan untuk aktif dalam kelompok. Hal ini dapat ditunjukkan dari perubahan tindakan yang dilakukan oleh siswa, karena siswa yang awalnya takut maupun ragu-ragu dalam menyampaikan pendapat sekarang sudah lebih percaya diri. Sehingga, dalam kegiatan pembelajaran tidak hanya didominasi oleh siswa yang pintar saja tetapi oleh seluruh siswa.

Perbaikan-perbaikan yang dilakukan oleh guru dalam pembelajaran matematika selama siklus I dan siklus II sangat membantu siswa untuk memahami konsep pertidaksamaan linier kuadrat dua variabel, sehingga pada siklus III tidak terdapat lagi permasalahan yang berarti dalam pembelajaran matematika. Hal ini dikarenakan kendala-kendala yang dihadapi pada siklus sebelumnya mampu diselesaikan melalui refleksi pada setiap siklusnya, sehingga prestasi belajar siswa pada materi pertidaksamaan linier kuadrat dua variabel mengalami peningkatan dari siklus ke siklus.

\section{Simpulan dan Saran}

Berdasarkan hasil penelitian dan pembahasan yang telah dipaparkan pada bab sebelumnya, dapat disimpulkan yaitu teknik mind map dapat meningkatkan prestasi belajar matematika siswa kelas X MIPA 7 SMA Negeri 1 Singaraja. Peningkatan ini terjadi karena berbagai tindakan-tindakan yang telah dilakukan oleh guru yaitu: (1) mengoptimalkan konsepkonsep yang telah dipelajari dengan memberikan catatan-catatan penting yang ditunjukkan pada bentuk mind map yang kemudian dikembangkan ke dalam LKPD (2) mengajak siswa untuk lebih banyak menerapkan konsep yang telah dipelajari baik melalui latihan soal, kuis dan tugas, dan (3) pemberian motivasi kepada siswa juga dapat dilakukan untuk membuat siswa lebih aktif dalam pembelajaran baik dalam diskusi kelompok maupun dalam menyampaikan hasil diskusi.

Berdasarkan temuan-temuan yang diperoleh dalam penelitan ini, dapat diajukan beberapa saran sebagai berikut. (1) Sebagai alternatif pembelajaran dalam pelaksanaan pembelajaran matematika, teknik mind map dapat dipertimbangkan untuk diterapkan, sehingga pembelajaran matematika dapat berlangsung lebih bermakna dan tidak monoton serta nantinya dapat meningkatkan kemampuan pamahaman konsep pada materi lain maupun untuk meningkatkan aspek kognitif lain dalam pembelajaran matematika; (2) Sebagai alternatif penilaian, teknik mind map dapat dijadikan penilaian keterampilan dari siswa untuk menentukan sejauh mana siswa mampu memahami konsep dan dapat menentukan keterkaitan antar konsep-konsep yang telah dipelajari sebelumnya, sehingga guru dapat menentukan ke mana arah pembelajaran yang perlu diberikan; (3) Bagi pembaca yang berminat untuk melaksanakan penelitian lebih lanjut dengan teknik mind map diharapkan agar memperhatikan kendala-kendala yang dialami selama pelaksanaan penelitian ini, sehingga dapat dijadikan sebagai bahan pertimbangan untuk perbaikan dan penyempurnaan pelaksanaan penelitian.

\section{Daftar Pustaka}

Buzan, Tony. 2008. How To Mind Map (Mind Map Untuk Meningkatkan Kreativitas). Penerjemah: Eric Suryaputra. Jakarta: PT Gramedia Pustaka Utama.

Dipayana, I. K. M., Gading, I. K., \& Japa, I. G. N. (2019). Pengaruh Pendekatan Pembelajaran Matematika Realistik Indonesia terhadap Hasil Belajar Matematika Ditinjau dari Minat Komputasi. Mimbar PGSD Universitas Pendidikan Ganesha, 7(3). https://ejournal.undiksha.ac.id/index.php/JJPGSD/article/view/19466/11529 
DePorter, Bobbi., Reardon, Mark., \& Singer-Nourie, Sarah. 2005. Quantum Teaching (Mempraktikkan Quantum Learning di Ruang-ruang Kelas). Penerjemah: Ary Nilandari. Bandung: Penerbit Kaifa.

DePorter, Bobbi., \& Hernacki, Mike. 2000. Quantum Learning (Membiasakan Belajar Nyaman dan Menyenangkan). Penerjemah: Alwiyah Abdurrahman. Bandung: Penerbit Kaifa.

Hamalik, Oemar. 2004. Psikologi Belajar dan Mengajar. Bandung: PT Sinar Baru Algensindo.

Komaidi, didik dan Wahyu Wijayanti. 2011. Panduan Lengkap PTK. Yogyakarta: Sabda Media.

Sagala, Syaiful. 2010. Konsep dan Makna Pembelajaran. Alfabeta: Bandung. 